\title{
Rescaling of Metropolitan Governance and Spatial Planning in Europe: an Introduction to the Special Issue
}

\author{
Karsten Zimmermann $^{1}$ (D) $\cdot$ Panagiotis Getimis $^{2}$
}

Received: 26 November 2015 / Accepted: 13 February 2017 / Published online: 1 March 2017

(c) Springer-Verlag Berlin Heidelberg 2017

\begin{abstract}
The article gives an introduction to the special issue about recent developments in metropolitan governance in Europe. The special issue seeks to contribute to a comparison of metropolitan governance with a particular emphasis on national policy initiatives. The presentation of recent developments in the six countries Germany, Italy, France, Poland, Spain and England follows a common framework. This framework is built on theories of rescaling and governance. All six countries have experienced dynamic changes in the scale and scope of metropolitan regionalism with different results. The contributions to the special issue show national policy initiatives as well as local case studies of metropolitan governance in terms of their history, structure and recent performance. The chapters show path-dependent developments in Germany, France and Spain as well as path-breaking changes in Poland, Italy and England. All in all, besides the fact that metropolitan regions are still high on the political agenda, a high degree of variation with regard to national policies remains.
\end{abstract}

Keywords Metropolitan Regions · Europe - Governance · Rescaling

Prof. Dr. Karsten Zimmermann

karsten.zimmermann@tu-dortmund.de

Prof. Dr. Panagiotis Getimis

getimisp@gmail.com

1 Fachgebiet Europäische Planungskulturen, Technische Universität Dortmund, August-Schmidt-Straße 6, 44227 Dortmund, Germany

2 Institut für Politikwissenschaft, Technische Universität Darmstadt, Dolivostraße 15, 64293 Darmstadt, Germany

\section{Re-Scaling stadtregionaler Governance und Planung in Europa: eine Einleitung zum Themenheft}

Zusammenfassung Der Beitrag leitet das Themenheft zu den jüngsten Entwicklungen in Metropolregionen und darauf bezogene Governance-Strategien in verschiedenen europäischen Staaten ein. Das Themenheft will insbesondere einen Beitrag zur vergleichenden Governance-Forschung leisten und legt einen Schwerpunkt auf nationale politische Initiativen, die Metropolregionen zum Gegenstand haben. Die Darstellung der gegenwärtigen Veränderungen in Deutschland, Italien, Frankreich, Polen, Spanien und England folgt einem einheitlichen Rahmen. Dieser bezieht sich auf Governance-Ansätze und Theorien der Reskalierung (rescaling) von Staatlichkeit. Alle sechs Staaten haben in dieser Hinsicht Veränderungen erlebt, die ganz unterschiedliche Resultate zeigen. Die Beiträge in diesem Heft gehen auf nationale Initiativen und Politikmuster ein, beschreiben aber auch Metropolregionen als Fallstudien. Während Deutschland, Frankreich und Spanien pfadabhängige Entwicklungen zeigen, weisen Polen, Italien und auch England markante Brüche auf. Es lässt sich schlussfolgern, dass Metropolregionen in allen Staaten auf der politischen Agenda bleiben, zugleich aber eine erhebliche Variation in den Strategien und Resultaten zu beobachten ist.

Schlüsselwörter Metropolregionen · Europa . Governance $\cdot$ Re-Scaling

\section{Introduction}

With this special issue of Raumforschung und Raumordnung we want to introduce and discuss recent changes in 
national policy frameworks for the creation of metropoli$\tan$ governance in some European states. The history of metropolitan institutions in the 20th century is all about the tension and misfits between institutional arrangements and functional interdependencies, usually interpreted as urban problems, particularly urban sprawl and residential segregation, in agglomeration economies. Political and administrative jurisdictions usually do not coincide with changes in the pattern of the urban production and consumption system (Savitch/Vogel 2000). Rapid urbanization in metropolitan regions permanently produces new demands for space (functional territory), while political and administrative units (institutional territory) lag behind the dynamic transformations (Lefèvre 1998).

David Harvey very precisely describes the problem as follows: "[Local government] boundaries do not necessarily coincide with the fluid zones of urban labor and commodity markets or infrastructural formation; and their adjustment through annexation, local government reorganization, and metropolitan-wide cooperation is cumbersome, though often of great long-term significance. Local jurisdictions frequently divide rather than unify the urban region, thus emphasizing the segmentations (such as that between city and suburb) rather than the tendency toward structured coherence and class-alliance formation" (Harvey 1989: 153). Iris Marion Young and also the International Metropolitan Observatory Group have addressed the impact of these developments on our democracies (Young 2000: 196 ff.; Sellers/ Kübler/Walks et al. 2013; see also Kelleher/Lowery 2004; Kübler 2012).

Three main strands of theoretical approaches have dominated the academic debate on metropolitan governance in recent decades: the metropolitan reform (or consolidation) approach, the public choice approach and neo-regionalism (see for an overview Norris 2001; Heinelt/Kübler 2005; Blatter 2007; Kübler 2012; Christmann 2014). Geographers, sociologists, political scientists, economists, planners and recently scholars from geo-sciences (transport, computer science) have contributed to this inter-disciplinary debate, offering different theoretical and methodological insights.

We will briefly present these three main strands of thought and their contribution to the academic debate and then we will focus on important dimensions of our methodological framework considering the politics of scale, for the comparative analysis of metropolitan areas in the context of multi-level governance. Finally, we will refer to important aspects of the contributions to this special issue, which highlight neglected facets of national policies on metropolitan governance in six European countries (Germany, France, Italy, UK, Poland, and Spain). Poland, France, Italy and the UK have been chosen because farreaching changes have taken place in these countries re- cently. In all four countries new national regulations have changed the conditions for metropolitan governance substantially, while in Germany as well as in Spain such interventions are so far unknown.

\section{The academic debate on metropolitan governance}

The controversial debate among the two main strands of theory, the public choice and the metropolitan reform approaches, started in the 1950s and actually overwhelmed the discussion until the end of the century. The main arguments which were derived from these two opposing positions refer to the classical topic of the optimal size of a jurisdiction, the main role of which is to deliver public services effectively, and enhancing local democracy and citizen participation (Kübler 2012; see Dahl/Tufte 1973). On the one hand, metropolitan reform theorists argue that the fragmentation of metropolitan space in many jurisdictions is a major problem due to the lack of effectiveness and efficiency, shortcomings in service delivery, and dispersion of resources (see Blatter 2007). They propose alternative consolidation arrangements: from annexation to obligatory amalgamations and the establishment of new metropolitan units or the second tier of local government. On the other hand, public choice theorists support the existing institutional fragmentation, highlighting various advantages: the adjustment of local politics to the needs of citizens, the importance of historical and political local identities, the benefits of the proximity of service delivery, public participation, and finally the fact that political leaders are closer to citizens. Thus, they reject the creation of metropolitan institutions but propose voluntary ad hoc co-operation schemes, which are more flexible for the mismatched catchment areas (inter-municipal cooperation, networks and private-public partnerships) (Ostrom/Tiebout/Warren 1961).

The aforementioned arguments of the academic debate are reflected in the diverse ideas and policy recommendations for policymakers (politicians, high-level administrators, business leaders), who have influenced the decision making processes towards either 'loose' or 'hard' institutional forms of metropolitan governance in several city regions in Europe (Salet/Thornley/Kreukels 2003; Heinelt/Kübler 2005; Hulst/van Montfort 2007; Nelles 2012; Christmann 2014).

A third and distinct theoretical approach developed in the 1990s is the neo-regionalism that dominated the current debate on metropolitan governance (Norris 2001; Heinelt/ Kübler 2005). Initially the innovative work of economic geographers (Cooke/Morgan 1994; Storper 1997) was very decisive in explaining how economic growth can be stimulated at the regional level, based on private and public 
actors involved in 'regional innovation networks' (Cooke/ Morgan 1998). Neo-regionalism shifts the framework of spatial analysis from the city to the region and the supranational level. Localities are more and more exposed to globalization and internationalization. Metropolitan areas are forced to compete in the international market for new investments, while municipalities, beyond service delivery, have to focus on place-based entrepreneurship, mobilization of endogenous potential and economic development (Norris 2001). "Glocalism", a concept developed in the 1980s by Swyngedouw (1992), incorporates these two parallel contradictory dynamics of globalization and localism. In recent years, as will be shown by the contributions of this special issue, metropolitan institutions are moving in both directions: on the one hand they aim to better position the metropolis in the international competition of city regions, and on the other hand they have to care about local, internal functional coherence and socio-economic balance.

In a similar vein, Keating (1998), from a political science perspective, highlights the resurgence of the regions as territorial and political sub-national administrative units. Keating's thesis for the importance of the 'region' is developed along the same lines as Jessop's argumentation concerning the 'hollowing-out' of the state (Jessop 2002) due to driving forces both from above (globalization) and from below (regional/local state).

Other academics have criticised the new regionalism approach. They argue that neo-regionalism is shifting the argument from a social reproduction justification aiming at the redistribution of resources, to a rationale of marketled development aiming at economic growth. The dominance of production and competition issues leads to a neglect of social reproduction issues (Jonas/Ward 2007; see also Blotevogel/Schmitt 2006; Salet/Thornley 2007). Neoregionalists are further criticized for giving emphasis to the changing geographies of economic activities at the cityregional level, neglecting the increase of socio-economic discrepancies and adopting the hegemonic neoliberal doctrine (e.g. Brenner 2003; Swyngedouw 2004). The critical approaches vary from a hard accusation highlighting the 'poor framework' of neo-regionalists (Lovering 1997) to a sympathetic critique - the region as an 'object of mystery' (Harrison 2006; Harrison/Growe 2014). With the compilation of this special issue we do not want to perpetuate this debate. Rather, we want to illustrate that recent changes in metropolitan governance show specific paths in their respective national contexts. Hence, it is hard to find universal conceptual approaches with descriptive or even prognostic quality. In this regard we join in most of the criticism of the new regionalism approach and we also think that the threefold distinction between old and new regionalism and public choice theory is not sufficient for describing what is happening in the empirical reality. We believe that the approach of politics of scale is most appropriate for understanding these dynamic processes of creating, abolishing and adapting metropolitan regions in political environments characterized by contested central-local relationships.

\section{The relevance of the 'politics of scale' in a comparative analysis of metropolitan governance}

We argue that the theoretical approaches deriving from the 'politics of scale' (Smith/Ward 1987; Swyngedouw 1992; Swyngedouw 2004) and re-territorialization of governance structures (Brenner 2003; Blatter 2007) offer a fruitful framework for the comparative analysis of the transformations of metropolitan governance institutions and practices in specific national contexts. We do this for two reasons:

First, the widely accepted distinction between the three approaches of metropolitan governance seems to be weak in a heuristic and a normative sense. As will be shown in the contributions to this special issue, the multi-scalar reality of metropolitan regions calls for new analytical approaches and defies one-scaled and one-dimensional institutional solutions. Second, we see shortcomings in the international comparative work on metropolitan governance. Quite a few edited volumes have been published, but most of them represent collections of case studies without taking national policy initiatives sufficiently into account. ${ }^{1}$

In the interpretative framework of 'restructuring of statehood' (Brenner 1998; Brenner 2009) and the shift from 'government' to 'governance' (Le Galès 1998), city regions are permanently challenged to change their governing institutions. Moreover, seen from the perspective of multilevel governance (Hooghe/Marks 2003), new existing institutional boundaries are overcome by the emergence of 'soft spaces' of action with 'fuzzy' boundaries (Allmendinger/ Haughton 2012). Actors in metropolitan areas reorganize their strategies, while institutions change 'scalar configurations', shifting competences and power upwards, downwards, and horizontally ('jumping scales'). Scales are restructured, redefined and contested ('flexible political geometry'), depending on the socio-spatial transformation and the actor constellation (Swyngedouw 2004).

Relational approaches enriched the scalar debate, asserting that a particular scale is embedded in other scales and interrelationships among scales are produced through political struggle ('relational and unbounded' conceptions of regions; Allen/Massey/Cochrane 1998; Amin 2004). Accord-

\footnotetext{
1 The edited volume of Hulst and van Montfort (2007) is an exception but gives more emphasis to inter-municipal cooperation in general. Governance and planning of metropolitan regions is not the focus of the book.
} 
ingly, we cannot adequately explain the complexity of governing processes at the metropolitan scale without analysing its relationship to other scales and the transfer of political power among them. Thus, it is important to analyse the vertical and horizontal power relations in the framework of the re-composition of the political (Le Galès 1998), in other words to explore not only the "hollowing out" of the state but also the "filling in" of politics at all scales (see the important contribution by Goodwin/Jones/Jones 2005: 424). Focusing on the reconstruction of the political in this way, we argue that deterministic interpretations of 'rescaling', due to general driving forces (e.g. globalization, privatization, Europeanization) can be avoided, allowing room for choices and the struggles of political actors in the metropolis (Jonas/Ward 2007; Paasi 2010).

Given these trajectories of change, how can we explain the variety of metropolitan institutions among EU countries (or even in the same country) and how can we interpret their transformations across time? What are the reasons for change, from consolidated forms to the abolishment of metropolitan institutions and then again to the resurgence of new forms?

\section{A comparative view on the chapters}

The contributions to this special issue show that in all six countries economic competitiveness is one of the main drivers for the creation of metropolitan regions. Whilst in Germany the influence of national government has remained rather weak, Italy, France, Poland and to a limited degree the UK (in 2009 and 2011) have changed national laws and created incentive structures to foster the creation of city regions. However, as the papers by Fedeli and Geppert show, economic competitiveness was not the only argument for metropolitan reforms. Cost efficiency, austerity policies and the simplification of a multi-layered public administration are also strong arguments to be found in the respective reform debates (see Fedeli 2017; Geppert 2017). Spain is probably the country where the influence of national government is weakest.

Two aspects should be highlighted, which are often neglected in the comparative analysis of metropolitan governance:

- The path-dependence of metropolitan institutions, their transformations and the role of actor constellations

- The relevance of local context: how beliefs, concepts/ ideas, frames, narratives and knowledge define public discourse and guide metropolitan governance practices

\subsection{Path-dependence and change, actor constellation and leadership}

The history of metropolitan institutions is very rich in continuities and changes, dependent on state rescaling in each country. As Brenner (2009: 134) puts it: "The rescaling of state space never entails the creation of a 'blank slate' on which totally new scalar arrangements could be established, but occurs through a conflictual 'layering' process in which emergent rescaling strategies collide with, and only partially rework inherited landscapes of state scalar organization".

The different institutional and legal frameworks of states or even of sub-national units in the same state, as Zimmermann shows in four city regions in the German federal state in his paper (Zimmermann 2017), are a very important factor explaining the diversity of metropolitan governance forms. Similarly, the diversity of metropolitan governance models in Spain (ranging from a high degree of functional and institutionalized models like in Barcelona to urban areas with no metropolitan services, plans or policies such as in Murcia), as analysed in the paper by Tomàs in the current issue, is explained by the historically developed institutional setting (Tomàs 2017). The constitutional and legal framework in the 1970s and 1980s defined the balance of power among the new democratic central state and the new regional governments, which were given the power to establish or abolish metropolitan structures.

Metropolitan governance forms are highly path-dependent on inherited institutional structures and embedded spatial configurations. However, the specific 'metropolitan histories' are marked not only by continuities but also by changes, imposed by 'change agents' acting at different scales (Getimis/Reimer/Blotevogel 2014). Rescaling of power is intermingled with 'change agents' (Börzel/ Risse 2003) who try to overcome 'multiple veto points', either through 'arguing and bargaining', persuading opposed actors to redefine their goals and interests, or through majoritarian decisions and 'command and control', top-down policy measures that impose transformations.

Actors that take decisions at the national level concerning the general framework of metropolitan reforms (e.g. majorities in parliament), are very crucial in defining the leeway for action of city-regional actors. For example in the case of Italy, the new law on metropolitan regions foresees homogeneous forms of metropolitan institutions (e.g. defining boundaries) and leaves little room for variations (see Fedeli 2017). Fedeli (2017) argues: "Rather than identifying a definitive boundary, the law should have focused more attention on devices able to generate and regenerate 'territories of (for) policies', 'territories by design', which should be based on the reciprocal, even if temporary, engagement of actors on a specific problem". 
On the contrary, recent rescaling processes in the UK (Localism Act 2011) lead to the 'asymmetrical devolution' of powers allocated 'a la carte' by the central government to different cities or city regions. As Shaw and Tewdwr-Jones highlight in their contribution to this special issue: "This marks a clear shift from traditional approaches to sub-national governance in England, which tended to impose similar devolved arrangements on to a variety of metropolitan areas in the time-honoured tradition of "one size fits all"” (Shaw/Tewdwr-Jones 2017).

Similar trends concerning the enhanced room for manoeuvre of actors at the metropolitan level can be observed in Germany, where a heterogeneous multi-scaled situation prevails in most of the metropolitan regions (see Zimmermann 2017), and in France, where the tradition to institutionalize metropolitan co-operation through the creation of new metropolitan structures enables city/regional actors to create new metropolitan bodies (see Geppert 2017). However, compared to the German situation, the recent introduction of the métropole as a new layer for the organization of metropolitan governance in France follows a more (nation-) state-centric understanding of governance. Also in France, nationwide regulation prevails. However, the accentuation of a limited number of metropolitan regions that are expected to be economic growth engines of national relevance is similar to the German case.

In this special issue the paper by Fricke compares the changing concepts of metropolitan regions in different policy contexts, namely the European Union, France and Germany. These spatial concepts are related to underlying frames for spatial development such as polycentricity, competitiveness or integrated development. The comparative analysis explores how spatial concepts and policy ideas travel between policy contexts, referring to the concept of the "Travel of Ideas" of Czarniawska/Joerges (1996) (see Fricke 2017).

The role of metropolitan actors is also highlighted in the paper by Krukowska and Lackowska, included in this special issue. EU funding, the new instrument of Integrated Territorial Investment in particular, is utilized by the central state in Poland as a mechanism to facilitate cooperation among municipalities in city regions. However, local actors are given the freedom to choose the legal form of the metropolitan cooperation scheme. The result is a diversity of implemented solutions. This is called the "metropolitan colours of Europeanization" (Krukowska/ Lackowska 2017). Thus, Europeanization processes, despite some homogeneous imperatives, have multi-faceted impacts on metropolitan institutions, depending on the different responses from the actor constellations in every city.

A very decisive actor-related factor, often neglected in the metropolitan governance literature, is leadership.
Political leaders from various levels (municipalities, regions) can enact different leadership styles (visionary, consensus, city boss, caretaker), and accordingly employ different strategies ('power over'/authoritarian or "power to'/cooperative) at the metropolitan level, leading to success or failure (Haus/Heinelt 2005; Getimis/Hlepas 2006). This aspect is highlighted in Tomàs' contribution to this special issue. Concerning the political leadership enacted in seven Spanish metropolitan institutions, Tomàs distinguishes between three scenarios: dominance of regional leadership (Madrid, Seville); predominance of local leadership (Barcelona); mixture of the two (Bilbao, Valencia, Vigo, Murcia). Furthermore, Tomàs (2017) argues that "the failures and successes of various governance formulas can be understood by considering the attitudes of metropolitan representatives: the willingness to co-operate and find a common denominator in favour of the general interest".

\subsection{The relevance of local context: beliefs, concepts, ideas, frames, narratives}

Despite the fact that strong national schemes have been introduced in most countries presented in this special issue, local context seems to be the decisive factor for the success or failure of metropolitan governance. In none of the countries a clear common pattern can be detected. In particular in Germany and Spain the variety of metropolitan regionalism is the dominant pattern. But the application of national frameworks in Poland, Italy and to some extent in France has also resulted in very different solutions and nonsolutions. The chapters on France, Italy and Poland show resistance against state-led policies and intervention. Besides claims for autonomy we believe that local context matters in this regard. In urban and regional research the specificity of place and space has been highlighted in the past from different angles: specificity of 'locality' (Gregory/Urry 1985), historically rooted circumstances (Goodwin/Duncan 1985), 'urban regime' debate (Stone 1989), ideas as hegemonic frames that guide coalitions and city choices ("growth machine", Molotch 1976). However, most of these efforts remain in the framework of structurally determined human actions, derived either from rational choice models or from interest-based imperatives or exogenous driving forces.

We argue that interpretative and argumentative approaches can complement and highlight important aspects of metropolitan governance that are missing from the academic debate. The 'distinctiveness of a city' refers to the specific features and tacit processes in a city that generate meaning (Berking/Löw 2008). Analysing beliefs, shared values, concepts and underlying frames can be very useful to explain public discourses and interpret the concrete practices of actors in metropolitan contexts. Recent research has focused increasingly on these neglected aspects of 'sense- 
making' practices, which are not considered as guided by invisible 'driving forces' and external 'regularities', but as communicative interactions of social beings, trying to transform self-centred interests in public discourses (Frank/Gehring/Griem et al. 2014). Cultural perceptions and symbolic interpretations (Salet/Vermeulen/Savini et al. 2015) enrich the existing research, highlighting aspects such as metropolitan identities, symbolic frames, "Sinnhorizonte" and problem discourses (Barbehön/Münch/Haus et al. 2015).

In the paper by Tomàs on the comparative analysis of metropolitan institutions in seven Spanish agglomerations, the interesting topic of 'metropolitan narratives' is highlighted. These narratives reflect different actors' perceptions and definitions of the built environment, the periphery/centre relations, culture/ethnicity, stereotypic images of people, etc. The construction of narratives is related to the power relations within the metropolis. As Tomàs (2017) argues: "There might be a dominant narrative or competing narratives, depending on the configuration of local actors and the interrelations between public and private actors".

Summing up, one additional critical point should be added to the aforementioned two important aspects of the comparative analysis of metropolitan governance. Further research should not reduce its focus to the appropriate form of metropolitan governance for each agglomeration, but broaden its scope to include the content and objectives of metropolitan policies and practices. In the past, academics and practitioners have given priority to the issues of entrepreneurship, competition, and performance of metropoli$\tan$ institutions, while they undermined the issues of redistribution, local democracy, social justice, and environmental challenges. However, new problems are emerging in the European metropolis, like the permanent fiscal crisis and austerity measures, increased inequalities, and new uncontrolled migration flows of asylum seekers and immigrants. The question of how metropolitan practices and institutions should address these new challenges and problems remains open. A critical appraisal is required which not only focuses on criteria of performance and efficiency (output legitimacy), but also on criteria of democracy, transparency (input and through-put legitimacy), social justice and social cohesion (Young 2000: 196 ff.; Zimmermann 2014).

\section{References}

Allen, J.; Massey, D.; Cochrane, A. (1998): Rethinking the Region. London.

Allmendinger, P.; Haughton, G. (2012): The evolution and trajectories of English spatial governance: 'neoliberal' episodes in planning. In: Planning Practice and Research 28, 1, 6-26.

Amin, A. (2004): Regions unbound: towards a new politics of place. In: Geografiska Annaler Series B - Human Geography 86, 1, 3344.
Barbehön, M.; Münch S.; Haus, M.; Heinelt, H. (2015): Städtische Problemdiskurse. Lokalpolitische Sinnhorizonte im Vergleich. Baden-Baden.

Berking H.; Löw M. (eds.) (2008): Die Eigenlogik der Städte. Neue Wege für die Stadtforschung. Frankfurt am Main.

Blatter, J. (2007): Governance - theoretische Formen und historische Transformationen. Baden-Baden.

Blotevogel, H.H.; Schmitt, P. (2006): „European Metropolitan Regions" as a New Discursive Frame in Strategic Spatial Planning and Policies in Germany. In: Die Erde 137, 1-2, 55-74.

Börzel, T.A.; Risse, T. (2003): Conceptualizing the domestic impact of Europe. In: Featherstone, K.; Radaelli, C.M. (eds.): The politics of Europeanization. Oxford, 57-80.

Brenner, N. (1998): Global cities, glocal states: global city formation and state territorial restructuring in contemporary Europe. In: Review of International Political Economy 5, 1, 1-37.

Brenner, N. (2003): Metropolitan Institutional Reform and the Rescaling of State Space in Contemporary Western Europe. In: European Urban and Regional Studies 10, 4, 297-324.

Brenner, N. (2009): Open questions on state rescaling. In: Cambridge Journal of Regions, Economy and Society 2, 1, 123-139.

Christmann, A. (2014): Von Government zu Governance? Acht europäische Metropolregionen im Vergleich. In: Zeitschrift für vergleichende Politikwissenschaft 8, supplement 1, 141-167.

Cooke, P.; Morgan, K. (1994): Growth regions under duress: renewal strategies in Baden Württemberg and Emilia-Romagna. In: Amin, A.; Thrift, N. (eds.): Globalization, Institutions and Regional Development in Europe. Oxford, 91-117.

Cooke, P.; Morgan, K. (1998): The Associational Economy. Oxford.

Czarniawska, B.; Joerges, B. (1996): Travels of Ideas. In: Czarniawska, B.; Sevón, G. (eds.): Translating Organizational Change. Berlin, New York, 13-48.

Dahl, R.A.; Tufte, E.R. (1973): Size and Democracy, Stanford.

Fedeli, V. (2017): Metropolitan Governance and Metropolitan Cities in Italy: Outdated Solutions For Processes of Urban Regionalisation? In: Raumforschung und Raumordnung 75, 3.

Frank, S.; Gehring, P.; Griem, J.; Haus, M. (eds.) (2014): Städte unterscheiden lernen. Zur Analyse interurbaner Kontraste. Birmingham, Dortmund, Frankfurt, Glasgow. Frankfurt am Main. = Interdisziplinäre Stadtforschung 19.

Fricke, C. (2017): Metropolitan Regions as a Changing Policy Concept in a Comparative Perspective. In: Raumforschung und Raumordnung 75,3 .

Geppert, A. (2017): Vae victis! Spatial Planning in the Rescaled Metropolitan Governance in France. In: Raumforschung und Raumordnung 75, 3.

Getimis P.; Hlepas N. (2006): Aspects of leadership styles: an interaction of context and personalities. In: Bäck, H.; Heinelt, H.; Magnier, A. (eds.): The European Mayor. Political Leaders in the Changing Context of Local Democracy. Wiesbaden, 177-199.

Getimis, P.; Reimer, M.; Blotevogel, H.H. (2014): Multiple trends of continuity and change. In: Reimer, M.; Getimis P.; Blotevogel, H.H. (eds.): Spatial planning systems and practices in Europe: A comparative perspective on continuity and changes. London, 278305.

Goodwin, M.; Duncan, S. (1985): The local state and local economic policy. Political mobilisation or economic regeneration. In: Capital and Class 9, 3, 14-36.

Goodwin, M.; Jones, M.; Jones, R. (2005): Devolution, constitutional change and economic development: explaining and understanding the new institutional geographies of the British state. In: Regional Studies 39, 4, 421-436.

Gregory, D.; Urry, J. (eds.) (1985): Social relations and spatial structures. Basingstoke.

Harrison, J. (2006): Re-reading the New Regionalism: A Sympathetic Critique. In: Space and Polity 10, 1, 21-46. 
Harrison, J.; Growe, A. (2014): From places to flows? Planning for the new 'regional world' in Germany. In: European Urban and Regional Studies 21, 1, 21-41.

Harvey D. (1989): The Urban Experience. Oxford.

Haus, M.; Heinelt, H. (2005): How to achieve governability at the local level? Theoretical and conceptual considerations on a complementarity of urban leadership and community involvement. In: Haus, M.; Heinelt, H.; Stewart, M. (eds): Urban Governance and democracy. Leadership and community involvement. New York, 12-39.

Heinelt, H.; Kübler, D. (eds.) (2005): Metropolitan Governance. capacity, democracy and the dynamics of place. London, New York.

Hooghe, L.; Marks, G. (2003): Unraveling the Central State, but how? Types of Multi-Level Governance. In: American Political Science Review 97, 2, 233-243.

Hulst, R.; van Montfort, A. (eds.) (2007): Inter-Municipal Cooperation in Europe. Dordrecht.

Jessop, B. (2002): The Future of the Capitalist State. Cambridge.

Jonas, A.E.G.; Ward, K.G. (2007): Introduction to a Debate on CityRegions: New Geographies of Governance, Democracy and Social Reproduction. In: International Journal of Urban and Regional Research 31, 1, 169-178.

Keating, M. (1998): The New Regionalism in Western Europe: Territorial Restructuring and Political Change. Cheltenham.

Kelleher, C.; Lowery, D. (2004): Political Participation and Metropolitan Institutional Contexts. In: Urban Affairs Review 39, 6, 720757.

Krukowska, J.; Lackowska, M. (2017): Metropolitan Colours of Europeanization. Institutionalization of Integrated Territorial Investment Structures in the Context of Past Cooperation in Metropolitan Regions. In: Raumforschung und Raumordnung 75, 3.

Kübler, D. (2012). Governing the metropolis: Towards kinder, gentler democracies. In: European Political Science 11, 3, 430-445.

Lefèvre, C. (1998): Metropolitan government and governance in western countries: a critical review. In: International Journal of Urban and Regional Research 22, 1, 9-25.

Le Galès, P. (1998): Regulations and Governance in European Cities. In: International Journal of Urban and Regional Research 22, 3, 482-506.

Lovering, J. (1997): Theory led by policy: the inadequacies of the "new regionalism' (illustrated from the case of Wales). In: International Journal of Urban and Regional Research 23, 2, 379-395.

Molotch, H. (1976): The City as a Growth Machine: Toward a Political economy of Place. In: American Journal of Sociology 82, 2, 309332.

Norris, D.F. (2001): Prospects for regional governance under the new regionalism: economic imperatives versus political impediments. In: Journal of Urban Affairs 23, 5, 557-571.
Nelles, J. (2012): Comparative Metropolitan Policy. Governing beyond local boundaries in the imagined metropolis. London.

Ostrom V.; Tiebout C.M.; Warren R. (1961): The Organization of Government in Metropolitan Areas: A Theoretical Inquiry. In: American Political Science Review 55, 4, 831-842.

Paasi, A. (2010): Regions are social constructs, but who or what 'constructs' them? Agency in question. In: Environment and Planning A $42,10,2296-2301$.

Salet, W.; Thornley, A.; Kreukels, A. (eds.) (2003): Metropolitan Governance and Spatial Planning. Comparative Case Studies of European City Regions. London.

Salet, W.; Thornley, A. (2007): Institutional influences on the integration of multilevel governance and spatial policy in European cityregions. In: Journal of Planning Education and Research 27, 2, 188-198.

Salet, W.; Vermeulen, R.; Savini, F.; Dembski, S. (2015): Planning for the new European metropolis: functions, politics, and symbols. In: Planning Theory and Practice 16, 2, 251-275.

Savitch, H.V.; Vogel, R.K. (2000): Paths to new regionalism. In: State and Local Government Review 32, 3, 158-168.

Sellers, J.M.; Kübler, D.; Walks, A.R.; Walter-Rogg, M. (2013): The political ecology of the metropolis. Colchester.

Shaw, K.; Tewdwr-Jones, M. (2017): "Disorganised Devolution": Reshaping Metropolitan Governance in England in a Period of Austerity. In: Raumforschung und Raumordnung 75, 3.

Smith, N.; Ward, D. (1987): The Restructuring of Geographical Scale: Coalescence and Fragmentation of the Northern Core Region. In: Economic Geography 63, 2, 159-182.

Stone C.N. (1989): Regime Politics. Governing Atlanta 1946-1988. Lawrence.

Storper, M. (1997): The Regional World: Territorial Development in a Global Economy. New York.

Swyngedouw, E. (1992): The Mammon Quest: "Glocalisation", Interspatial Competition and the Monetary Order: the Construction of New Scales. In: Dunford, M.; Kafkalas, G. (eds.): Cities and Regions in the New Europe. London, 39-68.

Swyngedouw, E. (2004): Globalisation or 'Glocalisation'? Networks, Territories and Rescaling. In: Cambridge Review of International Affairs 17, 1, 25-48.

Tomàs, M. (2017): Explaining Metropolitan Governance. The Case of Spain. In: Raumforschung und Raumordnung 75, 3.

Young, I.M. (2000) Inclusion and Democracy. Oxford.

Zimmermann, K. (2014): Democratic Metropolitan Governance: Experiences in five German Metropolitan Regions. In: Urban Research and Practice 7, 2, 182-199.

Zimmermann, K. (2017): Re-Scaling of Metropolitan Governance in Germany. In: Raumforschung und Raumordnung 75, 3. 